\title{
TINJAUAN HUKUM PERJANJIAN YANG TELAH DALUWARSA TERHADAP UTANG-PIUTANG YANG DILAKUKAN DI BAWAH TANGAN BERDASARKAN HUKUM POSITF DI INDONESIA(Contoh Kasus Putusan Pengadilan Negeri Jakarta Pusat Nomor 538/Pdt.G/2014/PN.JKT.PST)
}

\author{
Imelda Septy Febrian \\ (Mahasiswa Program S1 Fakultas Universitas Tarumanagara) \\ (Email : Sefty.febrian@yahoo.co.id)
}

\section{Hanafi Tanawijaya}

(Corresponding Author)

(Dosen Fakultas Hukum Universitas Tarumanagara.Meraih Sarjana Hukum pada Fakultas Hukum Universitas Tarumanagara, Magister Hukum pada Fakultas Hukum Universitas Tarumanagara)

(Email: hanafitanawijaya@gmail.com)

\begin{abstract}
In practice, borrowing money is one of the means to get funds needed by humans. However, with the development of the era of borrowing and borrowing, there must be strong evidence to prove that there has been a loan lending event. in practice the agreement is carried out either in writing or by word of mouth or written under the hand, in accordance with the demand for it must be made in the presence of good faith and legal certainty. In making an agreement usually given a predetermined period of time based on the agreement of the parties. And if the agreement has expired the time period has been set then in the agreement the debt is past its term. But in this case the agreement was expired and the creditor had only collected the debt to the debtor for 34 years. What if the creditor collects the debt that has passed this time and in the Islamic law the debt must be paid even though the person who has the debt has died. The author examines this problem by using normative legal research methods supported by interviews with people who are experts in the field of Islamic law and law. In this agreement, it can cause losses to the creditor. As a result, in Article 1362 of the Civil Code, it is said that if a default occurs, there is a compensation.
\end{abstract}

Keywords: Expiration in Positive Law 


\section{Pendahuluan}

\section{A. Latar Belakang}

Pada perkembangan era modernisasi saat ini, juga ada praktik perjanjian peminjaman uang dari satu orang atau lebih untuk memenuhi kebutuhan manusia. Pada praktiknya metode ini merupakan cara untuk memenuhi kebutuhannya. Namun dengan seiring perkembangan zaman, pinjam meminjam yang dilakukan harus ada alat bukti yang kuat untuk membuktikan, bahwa telah terjadinya adanya suatu peristiwa pinjam meminjam. Dengan demikian, praktik-praktik yang dilakukan untuk melakukan perjanjian itu dilakukan baik dengan secara tertulis atau dengan secara lisan maupun tertulis dibawah tangan, sesuai dengan tuntutan terhadapnya harus dibuat dengan adanya itikad baik dan kepastian hukum.

Dalam hukum perjanjian memiliki sifat terbuka, selain itu hukum perjanjian merupakan sebagai hukum pelengkap. Sehingga siapapun bisa mengadakan kesepakatan, dengan mengganggu pihak lain secara umum dalam segala hal. Disimpulkan, kebersediaan menyatukan suatu keinginan antara dua pihak, atau sejumlah orang berkepentingan, ini juga bunyi pada Pasal 1313 KUHPerdata, yang memaknai perjanjian itu sendiri. Pemahaman menyangkut perjanjian, juga dirumuskan Subekti, yakni perjanjian adalah suatu peristiwa dimana seseorang berjanji kepada seseorang lainnya atau dimana dua orang itu saling berjanji untuk melaksanakan sesuatu hal ${ }^{1}$. Hukum perjanjian memang bersifat terbuka akan tetapi terdapat pengaturan-pengaturan mengenai perjanjian yang harus diikuti oleh kedua belah pihak yang berkepentingan, dimana ketentuan-ketentuan tersebut merupakan syarat mutlak yang harus dipenuhi sebagimana dinyatakan dalam ketentuan pasal 1320 KUHPerdata, perjanjian-perjanjian yang dilakukan oleh pihak-pihak, baru akan sah apabila telah memenuhi syarat sahnya suatu perjanjian yaitu :

\footnotetext{
${ }^{1}$ Ibid., hal. 1.
} 
1. Sepakat mereka yang mengikatkan diri

Artinya kedua belah pihak dalam suatu perjanjian harus mempunyai keinginan yang bebas untuk mengikatkan diri untuk melakukan perjanjian dan keinginan itu harus dinyatakan dan pernyataan tersebut dapat dilakukan dengan tegas atau secara diam ${ }^{2}$. Akibat hukum akan timbul jika terjadi perjumpaan antara kehendak dan pernyataan antara para pihak yang mengadakan perjanjian. Ada 4 (empat) teori yang menjelaskan tentang apakah perjanjian itu terjadi manakala timbul ketidaksesuaian antara kehendak dan pernyataan :

a. Teori kehendak (Wilstheorie); Teori ini mengajarkan bahwa telah adanya kesepakatan yang terjadi pada saat kehendak diterima oleh pihak penerima. Contohnya dengan menuliskan surat.

b. Teori pengiriman (verzendtheorie); Teori ini mengajarkan bahwa kesepakatan terjadi pada saat penerima telah menyatakan maka dikirimkan oleh pihak yang menerima. tawaran.

c. Teori pengetahuan (vernemingstheorie); Teori ini memberitahukan kepada pihak yang menawarkan bahwa seharusnya sudah mengetahui tawarannya diterima. d. Teori kepercayaan (vertrouwenstheorie); Teori ini mengajarkan bahwa kesepakatan itu terjadi pada saat pernyataan kehendak dianggap layak diterima oleh pihak yang menawarkan. ${ }^{3}$

Keempat teori tersebut memilki segi positif dan negatif karenanya tidak dapat digunakan secara konsekuen tanpa adanya pemeriksaan. Pada umumnya pernyataan yang telah diberikan seseorang adalah sesuai dengan kehendak, namun ada juga kemungkinan

\footnotetext{
${ }^{2}$ Guse Prayudi, Seluk Beluk Perjanjian,Cetakan ke-2, (Yogyakarta:Pustaka Pena,2007), hal. 6

${ }^{3}$ Mariam Darus Badrulzaman, (Kompilasi Hukum Perikatan, (Bandung:Citra Aditya Bakti,2001), hal 74.
} 
ketidaksesuaian antara kehendak dan pernyataan, ini dimungkinkan dalam tiga hal sebagai berikut :

1) Pernyataan tidak diinginkan;

2) Pernyataan betul diinginkan, namun tidak dalam arti sebagaimana ditafsirkan pihak lawan;

3) Pernyataan diinginkan sesuai dengan yang dimaksud oleh pihak lawan, tapi akibat hukumnya tidak diinginkan.

Sejatinya kata sepakat terjadi dengan pernyataan kehendak dari para pihak. Pernyataan atau kehendak tersebut harus tertuju pada akibat hukum yang diinginkan, yaitu pihak yang bertindak memunculkan kepercayaan pada pihak lainnya bahwa kehendaknya itu tertuju pada terbentuknya perjanjian.

2. Cakap untuk membuat suatu perjanjian

Kecakapan berarti orang yang telah cakap hukum dan tidak di bawah pengampua dan setiap orang adalah cakap untuk membuat perjanjian kecuali orangorang yang menurut undang-undang dinyatakan tidak cakap hukum. Orang-orang yang tidak cakap hukum menurut Undang-undang diatur didalam pasal 1330 KUHPerdata yaitu: orang-orang yang belum dewasa, mereka yang ditaruh dibawah pengampuan, perempuan yang telah kawin ${ }^{4}$.

3. Mengenai suatu hal tertentu

Artinya yang diperjanjikan dalam suatu perjanjian haruslah suatu barang yang cukup jelas atau tentunya yakni paling sedikit ditentukan jenisnya diatur dalam Pasal 1333 KUHPerdata) $)^{5}$.

\footnotetext{
${ }^{4}$ Ibid, hal. 9.

${ }^{5} \mathrm{Ibid}$, hal.12.
} 
4. Suatu sebab yang halal

Artinya yang diperjanjikan dalam suatu perjanjian haruslah suatu barang yang cukup jelas atau tentunya yakni paling sedikit ditentukan jenisnya diatur dalam Pasal 1333 KUHPerdata) ${ }^{6}$.

Dua syarat pertama dinamakan syarat subjektif, karena mengenai orang atau subyeknya hokum yang mengadakan perjanjian, sedangkan dua syarat yang terakhir dinamakan syarat Objektif karena mengenai perjanjiannya sendiri atau objek dari perjanjian yang telah para pihak sepakati. Objeknya pun harus jelas. Apabila syarat subjektif tidak dipenuhi maka maka perjanjian dapat dibatalkan sedangkan syarat objektif jika tidak dipenuhi maka batal demi hukum yang berarti bahwa tidak pernah dilahirkan suatu perjanjian dan tidak pernah ada perikatan maka dengan demikian tidak ada dasar untuk menuntut di muka hakim Pengadilan. ${ }^{7}$

Perjanjian utang termasuk kedalam jenis perjanjian pinjam-meminjam. Hal ini sebagaimana dimaksud dalam Bab Ketiga Belas Buku Ketiga KUHPerdata, yaitu di dalam Pasal 1754 KUHPerdata menyebutkan pinjam meminjam adalah perjanjian dengan mana pihak yang satu memberikan kepada pihak yang lain suatu jumlah tertentu barangbarang yang menghabis karena pemakaian dengan syarat bahwa pihak yang belakangan ini akan mengembalikan sejumlah yang sama pula.

Oleh karena itu, sangat jelas utang termasuk dalam perjanjian pinjam-meminjam. Perjanjian utang piutang yang terjadi karena peminjaman uang juga mempunyai jangka waktu yang telah ditentukan oleh para pihak berdasarkan kesepakatan yang para pihak buat. Perjanjian tersebut dapat memenuhi prestasi dan perjanjian hutang tersebut dapat pula mengakibatkan daluwarsa dikarenakan pihak-pihak tidak melaksanakan prestasinya sesuai dengan kesepakatan yang mereka telah buat.

\footnotetext{
${ }^{6}$ Ibid, hal.12.

${ }^{7}$ Ibid., hal. 17.
} 
Menurut Hartono Soerjopratiknjo, memberikan pengertian utang piutang adalah suatu perjanjian dimana pihak yang satu (kreditur) melepaskan atau menyerahkan dari pihak lainnya (debitur) suatu jumlah uang tertentu atau jumlah barang yang sama yang jenis dan keadaannya sama. ${ }^{8}$

Dalam bebarapa pengertian utang diatas pada dasarnya adalah memiliki kesama dengan yang telah dijelaskan diatas, bahwa utang merupakan hubungan hukum antara dua orang atau lebih dengan adanya hak dan kewajiban serta akan selesai apabila salah satu pihak sudah memenuhi prestasinya atau karena sebab-sebab lain yang dibolehkan undang-undang. Maka, dalam kehidupan sosial yang terjadi dimasyarakat yang tidak diatur dalam undang-undang, Al-Quran maupun Hadits Nabi, tetapi hal ini sudah menjadi adat kebiasaan yaitu sesuatu yang dikenal oleh masyarakat yang telah dilakukan baik berupa perkataan maupun perbuatan. Utang piutang pada dasarnya merupakan bentuk akad yang bercorak ta'awun (pertolongan) dan kasih sayang kepada pihak yang membutuhkan. Pada prakteknya utang piutang merupakan bagian dari mu'amalah yang mengandung unsur-unsur sosial yang sangat tinggi dan tidak ada nilai komersilnya, sesuai firman allah ${ }^{9}$ :

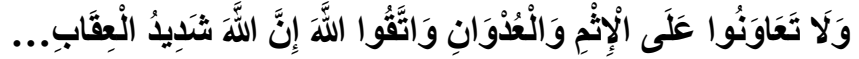

“...Dan tolong-menolonglah kamu dalam (mengerjakan) kebajikan dan takwa, dan jangan tolong-menolong dalam berbuat dosa dan pelanggaran." (QS. al-Maidah : 2) ${ }^{\mathbf{1 0}}$

Menurut H.Solihin memberikan penjelasan dalam ayat di atas bahwa pemberian pinjaman kepada seseorang harus didasarkan pada pemberian manfaat dari sesuatu yang

\footnotetext{
${ }^{8}$ Hartono Soerjopratiknjo, Hutang pihutang perjanjian-perjanjian pembayaran dan jaminan hypotik, cetakan ke-1, (Yogyakarta:Seksi Notariat Fakultas HukumUniversitas Gadjah Mada,1984), hal. 1.

${ }^{9}$ Peneliti, Wawancara, dengan Ustad. H. Solihin, S.Ag (Jakarta, Guru Agama dan Fiqih SMA AlChasanah, 17 Oktober 2018).

${ }^{10}$ Anonim, "Surat Al-Maidah ayat 2", https://www.bacaanmadani.com/2017/12/pengertian-hukum-dalildan-ketentuan.html, 17 Oktober 2018.
} 
telah dianjurkan agama atau jika tidak ada larangan dalam melakukannya. Dalam prinsip syariah utang, Allah memberikan rambu-rambu yaitu untuk menghindari penipuan dan perbuatan yang dilarang Allah lainnya. Pengaturan tersebut yaitu agar setiap transaksi utang dilakukan secara di catatkan dalam perjanjian dan dipersaksikan, ketetentuan ini terdapat dalam surat Al-Baqarah ayat 282 sebagai berikut sesuai firman Allah:

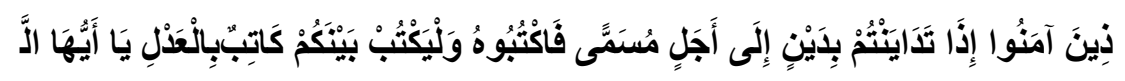

"Hai orang-orang yang beriman, apabila kamu bermu'amalah tidak secara tunai untuk waktu yang ditentukan, hendaklah kamu menuliskannya. Dan hendaklah seorang penulis di antara kamu menuliskannya dengan benar.”. (QS. Al-Baqarah: 282 $)^{11}$.

Adapun akad perjanjian yang mereka tulis dapat menimbulkan suatu perbuatan yang telah melanggar hukum dan melanggar perjanjian telah mereka buat maka dapat menimbulkan wanprestasi. Wanprestasi dalam hukum perjanjian tersebut apabila pihak berutang dianggap lalai karena lewatnya jangka waktu yang telah diperjanjikan pihak berutang apabila tidak menyerahkan barang atau untuk melakukan suatu perbuatan maka dalam pelaksanaannya prestasi harus terlebih dahulu ditagih ${ }^{12}$. Apabila seorang berutang sudah di berikan peringatkan atau ditagih janjinya maka tetap tidak membayarkannya, ia berada dalam keadaan lalai atau alpa dan terhadap si berutang dapat diberlakukan sanksisanksi yaitu berupa ganti rugi, pembatalan perjanjian, dan peralihan resiko. Peringatan atau teguran yang diberikan kepada si berutang diatur dalam Pasal 1238 KUHPerdata yang menyatakan bahwa : "Debitur adalah lalai apabila ia dengan surat perintah atau dengan sebuah akta sejenis itu telah dinyatakan lalai, atau demi perikatan sendiri ialah jika ini menetapkan bahwa si berutang harus dianggap lalai dengan lewatnya waktu yang ditentukan.”

\footnotetext{
11 Ibid

${ }^{12}$ Subekti, Hukum Perjanjian, Cetakan ke-20, (Jakarta: PT. Intermasa, 2004), hal. 46.
} 
Dalam suatu perjanjian yang telah lewatnya waktu dapat disebabkan oleh jangka waktu yang diperjanjikan dalam perjanjian tersebut. Lewatnya waktu menurut Pasal 1946 KUHPerdata adalah suatu alat untuk memperoleh suatu perikatan dengan lewatnya suatu waktu tertentu dan atas syarat-syarat yang ditentukan oleh Undang-undang. Daluwarsa ini diberikan jangka waktu selama 30 tahun, sesudah 30 tahun hukum menyesuaikan diri terhadap fakta dan keadaan yang tumbuh menjadi hukum.

Terkait dengan hal ini, maka penulis tertarik untuk menulis kasus tersebut untuk dikaji. Kasus ini terjadi pada tahun 1978 yaitu tentang perjanjian utang piutang secara tertulis, yang terjadi antara Penggugat yaitu Karsono, Tergugat yaitu Kalim, Turut Tergugat yaitu Badan Pertanahan Nasional Jakarta Pusat (BPN Jakarta Pusat). Pada waktu itu Karsono meminjamkan Uang kepada Kalim pada tanggal 22 Mei 1978 dengan jumlah sebesar Rp. 15.000.000.00,- (lima belas juta rupiah) dengan bunga 2,5\% per bulan dan denda sebesar Rp.2.000.00,- (dua ribu rupiah) per hari dengan jangka waktu selama dua Tahun, yang jatuh tempo pada tanggal 22 Mei 1980.

Bahwa sebagai jaminan pinjam uang tersebut, Tergugat memberikan jaminan 1 (satu) buah gedung di Pangeran Jayakarta No 101/C-7 Jakarta Pusat. Maka, untuk meyakinkan Penggugat, oleh sebab itu Tergugat juga memberikan 1 buah Tanda Bukti Akta Jual Beli (Alas Hak) Notaris No. 61 tanggal 23 Juni 1977 tanah hak Guna Bangunan Nomor 189/ Mangga Dua Selatan yang terletak di daerah DKI, Jakarta Pusat, Kecamatan Sawah Besar, desa/Kelurahan Mangga Dua selatan yang diuraikan dalam surat Ukur asal tanggal, 22 Mei 1975, No 452/1975, luas tanah yang dijual 69 meter persegi jual beli terjadi dengan harga sebesar Rp. 9.000.000,- (Sembilan Juta Rupiah). Tergugat menambahkan kembali berupa satu tanda bukti Akta Jual Beli (Alas Hak) Notaris No 60 tanggal 23 Juni 1977 Tanah Hak Guna Bangunan Nomor : 188/Mangga Dua Selatan yang terletak di daerah DKI Jakarta Pusat, Kecamatan Sawah Besar, Desa/Kelurahan Mangga Dua Selatan yang diuraikan dalam surat ukur tanggal 22 Mei 1975 No 452/1975, Luas 
Tanah 26 meter persergi dengan harga Rp. 3.500.000,-. Namun jaminan akta jual beli tanah (Alas Hak) Tergugat hanya sebesar Rp. 12.500.000,- (dua belas juta lima ratus ribu rupiah).

Bahwa perjanjian yang telah dilakukan oleh Penggugat dan Tergugat atas dasar perkawanan orang tua Tergugat, maka dari itu Penggugat memberikan pinjaman uang sehingga surat perjanjian peminjaman uang hanya ditulis dibawah tangan. Bahwa saat itu juga Tergugat pada tahun 1978 berusia 28 tahun yang mana Tergugat tidak mau mengakui bahwa telah melakukan perjanjian peminjaman uang kepada Penggugat. Terlebih, Tergugat mengatakan bahwa Tergugat selaku anak yang tunduk dan patuh pada orang tuanya dalam hal ini Tergugat hanya diperintah oleh almarhum ayahnya untuk sekedar menandatangani surat tersebut. Setelah itu, Penggugat melakukan somasi kesatu pada tahun 2007 karena penggugat mengingat bahwa jaminan satu buah gedung tersebut tidak bisa digunakan oleh penggugat karena masih dikuasai oleh tergugat. Dan gedung tersebut juga ditelantarkan oleh tergugat pada tahun 2006 sehingga penggugat harus berupaya menahan satu buah jaminan terhadap gedung tersebut sampai tergugat menyelesaikan kewajibannya kepada penggugat. Kemudian penggugat melakukan somasi kedua dan ketiga pada tahun 2007 bahwa penggugat tidak mendapatkan informasi di karenakan tergugat pindah alamat dan tidak ada pemberitahuan kepada penggugat.

Bahwa pada tahun 2013 penggugat baru mendapatkan informasi bahwa tergugat tinggal dijalan Mangga Besar 4J Nomor 3 Taman Sari Jakarta Pusat. Penggugat juga melakukan somasi kembali tetapi tidak pernah ditanggapi tergugat. Sehingga penggugat mengirim surat somasi (peringatan) yang intinya memberitahukan bahwa somasi kesatu, kedua, ketiga yang tidak pernah ditanggapi. Penggugat mengirim somasi yang intinya adalah menawarkan penyerahan jaminan 1 (Satu) buah gedung di jalan Pangeran Jayakarta Nomor 101 C-7 Jakarta dengan menghapuskan seluruh beban hutang yang timbul dari perjanjian pinjam uang tanggal 22 Mei 1978. Maka penggugat melakukan 
pendaftaran ke Pengadilan Negeri Jakarta Pusat pada tahun 2014 atas dasar gugatan wanprestasi karena Tergugat tidak ada itikad baik untuk melakukan pembayaran hutang yang dilakukan pada tahun 1978-1980 dan sampai gugatan didaftarkan ke Pengadilan. Bahwa penulis dalam skripsi ini membatasi ingin membahas Putusan Pengadilan Negeri yang telah memutus adanya daluwarsa walaupun sudah ada putusan Pengadilan Tinggi No 566/PDT.2015/PT.DKI dan Mahkamah Agung Nomor 2223/K/PDT/2016.

Berdasarkan uraian latar belakang yang telah dipaparkan di atas, penulis tertarik untuk membuat jurnal dengan judul : “TINJAUAN HUKUM PERJANJIAN YANG TELAH DALUWARSA TERHADAP UTANG PIUTANG YANG DILAKUKAN DI BAWAH TANGAN BERDASARKAN HUKUM POSITF DI INDONESIA(Contoh Kasus Putusan Pengadilan Negeri Jakarta Pusat Nomor 538/Pdt.G/2014/PN.JKT.PST)”.

\section{B. Perumusan Masalah}

Berdasarkan uraian latar belakang yang telah dipaparkan di atas, maka penulis mempaparkan beberapa permasalahan yang akan dibahas dalam Jurnal ialah:

1. Apakah dalam Hukum Perdata dan Hukum islam perjanjian utang piutang mengenal asas daluwarsa?

2. Apa yang menjadi pertimbangan hakim dalam memutus perkara Pengadilan Negeri Jakarta Pusat No. 538/Pdt.G/2014/PN.JKT.PST ?

\section{Metode Penelitian}

Tipe penelitian yang digunakan dalam penelitian ini adalah penelitian Hukum normatif. Penelitian hukum normatif adalah suatu proses untuk menentukan suatu aturan hukum, asas-asas hukum, maupun doktrin-doktrin hukum untuk menjawab 
permasalahan hukum yang dihadapi. ${ }^{13}$ Dalam penelitian hukum normatif di bagi menjadi 5 pendekatan, penulis menggunakan pendekatan kasus. Pendekan kasus dilakukan dengan cara melakukan telaah terhadap kasus-kasus yang berkaitan dengan isu yang dihadapi yang telah menjadi putusan pengadilan yang telah mempunyai kekuatan hukum tetap ${ }^{14}$. Sifat penelitian ini merupakan Preskriptif. Dalam penelitian ini, jenis data yang di gunakan oleh penulis adalah jenis data sekunder dengan dua bahan hukum yaitu Bahan Hukum Primer yang digunakan dalam penelitian ini yaitu Kitab Undang-Undang Hukum Perdata (KUHperdata) dan Putusan Pengadilan Negeri Jakarta Pusat Nomor 538/PDT.G/2014/PN.JKT.PST dan Bahan Hukum Sekunder semua publikasi tentang hukum yang bukan merupakan dokumen-dokumen resmi ${ }^{15}$. Bahan hukum sekunder yang penulis gunakan berupa buku-buku yang terkait tentang Hukum Perjanjian dan Daluwarsa. Dan juga didukung dengan adanya wawancara yakni dengan pihak-pihak dalam kasus, Dosen, Guru yang mempunyai ilmu agama. Penulis melakukan pengumpulan bahan dengan cara studi pustaka. Analisis bahan yang penulis lakukan berupa kegiatan memberikan telaah, yang dapat berarti menentang, mengkritik, mendukung, menambah atau memberi komentar dan kemudian membuat suatu kesimpulan terhadap hasil penelitian.

\section{PEMBAHASAN}

\section{A. Analisa}

1. Dalam Hukum Perdata dan Hukum islam perjanjian utang piutang mengenal asas daluwarsa

Pada kasus ini telah terjadi perjanjian pinjam meminjam uang antara Karsono dan Kalim. Pada saat itu perjanjian tersebut hanya dituliskan di bawah tangan, dan Kalim akan melunasi pembayaran tersebut dengan jangka waktu 2 tahun. Menurut

\footnotetext{
${ }^{13}$ Mukti Fajar ND dan Yulianto Achmad, Dualisme Penelitian Hukum Normatif dan Empiris,(Yogyakarta;Pustaka Belajar,2010), hal. 34.

${ }^{14}$ Peter Mahmud Marzuki, Penelitian Hukum, Cetakan ke-6 (Jakarta;Kencana, 2010)., hal. 134.

${ }^{15}$ Ibid., hal. 181.
} 
penulis ini termasuk ke dalam Pasal 1320 KUHPerdata dimana telah terpenuhi syarat-syarat sah dalam membuat perjanjian yang telah disepakati oleh kedua belah pihak. Tetapi setelah jangka waktu 2 tahun yang sudah ditentukan dalam perjanjian tersebut Debitur ingkar janji dalam perjanjian yang telah disepakatinya dan tidak ada itikad baik untuk membayar utangnya tersebut. Pada kasus ini juga bisa di lihat dari asas kepatutan yang diatur dalam Pasal 1339 KUHPerdata, yang menyatakan bahwa persetujuan tidak hanya mengikat apa yang dengan tegas ditentukan di dalamnya, melainkan juga segala sesuatu yang menurut sifat persetujuan dituntut berdasarkan keadilan, kebiasaan, atau undang-undang. Asas ini berkaitan dengan ketentuan mengenai isi perjanjian yang diharuskan oleh kepatutan berdasarkan sifat perjanjiannya. Asas kepatutan ini merupakan hubungan yang ditentukan juga oleh rasa keadilan yang ada di dalam masyarakat.

Didalam Pasal 1754 KUHPerdata juga menyatakan bahwa pinjam meminjam adalah perjanjian dengan mana pihak yang satu memberikan kepada pihak yang lain suatu jumlah tertentu barang-barang yang menghabis karena pemakaian dengan syarat bahwa pihak yang belakangan ini akan mengembalikan sejumlah yang sama pula. Maka dalam perjanjian pinjam meminjam uang harus adanya hak dan kewajiban yang harus dipenuhi oleh salah satu pihak. Dalam hal ini pihak kreditur sudah menagih utangnya tersebut kepada debitur tetapi tidak di hiraukan maka kreditur memberikan somasi beberapa kali kepada debitur guna untuk membayarkan utang kepada kreditur akan tetapi tidak dihiraukan oleh pihak debitur. Sehingga pada akhirnya setelah 34 tahun pihak kreditur mengajukan gugatan ke Pengadilan Negeri Jakarta Pusat untuk mendapatkan hak nya kembali yaitu mengenai pembayaran utang beserta bunga yang disepakati, karena selama 34 tahun tersebut pihak debitur tidak ada itikad baik untuk membayar utangnya tersebut. Di dalam KUHPerdata Pasal 1967 disebutkan bahwa segala tuntutan hukum, baik yang bersifat perbendaaan maupun yang bersifat perseorangan, hapus karena daluwarsa dengan lewatnya waktu 30 Tahun, sedangkan siapa yang 
menunjukan akan adanya daluwarasa itu tidak usah mempertunjukan suatu alas hak, lagi pula tak dapatlah dimajukan terhadapnya sesuatu tangkisan yang di dasarkan kepada itikadnya yang buruk. Maka dalam hal ini telah terjadi daluwarsa mengenai perjanjian yang telah dibuat dan gugatannya pun telah daluwarsa karena sudah lewat dari 30 tahun. Menurut teori daluwarsa yang telah ditentukan undangundang daluwarsa juga dapat memperoleh sesuatu apabila dengan lewatnya waktu dan dengan syarat-syarat tertentu (Acquisitieve Verjaring). Di dalam teori daluwarsa (Acquisitieve verjaring) menyebutkan nama-nama benda yang dapat diperoleh dengan jalur daluwarsa. Akan tetapi, penyebutan nama ini tidak dapat dikatakan berhasil undang-undang mengatakan bahwa barang tidak bergerak atau suatu piutang lain yang tidak mesti dibayar kepada penunjuk.

Dalam hal ini adapula Yurisprudensi terhadulu yang sama dengan kasus ini ialah Putusan Mahkamah Agung Tanggal 28-9-1955 Reg.No.21 K/Sip/1954, dalam pemeriksaan kasasi terhadap putusan Pengadilan Tinggi Medan Tanggal 3-101953. Terjadi hutang dalam 1912, kemudian yang berhutang meninggal dunia 1933. Diantara masa 1912 sampai tahun 1933 tidak ternyata si berpiutang membuat suatu tagihan ataupun sesuatu perbuatan lain yang sifatnya untuk mengingatkan adanya satu hutang. Bahwa pihak penggugat yang sekarang tergugat dalam kasasi mengemukakan dalil gugatannya bahwa hutang itu telah hapus karena lampau waktunya (Verjaring). Mahkamah agung berpendapat bahwa menurut hukum adat dalam perkara ini harus dipakai membenarkan dalil gugatan, bahwa yang demikian itu, dimana pihak tergugat dalam begitu lama membiarkan berlangsungnya piutang. Mengenai perjanjian tersebut dari salah satu pihak tidak memenuhi kewajibannya maka dapat menimbulkan permasalahan. Permasalahan tersebut adalah apabila pihak tidak memenuhi kewajibannya dapat dikatakan telah melakukan wanprestasi. Wanprestasi tersebut dapat menimbulkan kerugian bagi 
kreditur, sanksi atau akibat hukum bagi debitur yang wanprestasi yaitu ada 4 macam:

a. Debitur harus membayar ganti kerugian yang diminta oleh kreditur (Pasal 1243 KUHPerdata).

b. Pembatalan perjanjian disertai dengan ganti rugi (Pasal 1267 KUHPerdata).

c. Peralihan resiko kepada debitur sejak saat terjadinya wanprestasi (Pasal 1237 ayat 2 KUHPerdata).

d. Pembayaran biaya perkara apabila diperkarakan dimuka hakim (Pasal 181 ayat 1 HIR).

Menurut pendapat penulis mengenai analisis di dalam Hukum Islam orang yang memberikan pinjaman uang adalah sikap tolong menolong antara sesama manusia, Allah SWT dalam Al-Quran surat Al-Baqarah ayat 245:

Artinya: "Siapakah yang mau memberi pinjaman kepada Allah, pinjaman yang baik (menafkahkan hartanya di jalan Allah), Maka Allah akan meperlipat gandakan pembayaran kepadanya dengan lipat ganda yang banyak. dan Allah menyempitkan dan melapangkan (rezki) dan kepada-Nya-lah kamu dikembalikan

maka dari itu perjanjian tersebut haruslah dituliskan secara tertulis dibawah tangan karena dalam perjanjian utang piutang tersebut menimbulkan hak dan kewajiban yang harus dibuktikan dapat pula dengan dihadiri 2 orang saksi atau didepan pejabat notaris. Menurut pendapat penulis dalam perjanjian utang piutang tidak ada yang namanya daluwarsa karena di dalam Hukum Islam apabila seseorang yang mempunyai utang harus dibayarkan walaupun perjanjian tersebut telah habis jangka waktunya dan sampai debitur meninggal dunia utang tersebut tetap harus dibayar serta dapat dialihkan kepada ahli warisnya. Adapun hadits yang memperkuatnya 


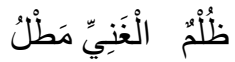

“penguluran (hutang) oleh orang yang mampu (membayar) adalah

kezaliman“[Hadist Riwayat Al Bukhari 2400-Fathul Bari- Muslim 1546]

Adapun menurut Riwayat At Tarmidzi :
\end{abstract}

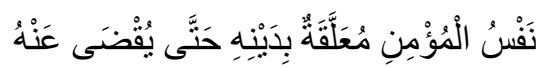

Di dalam Hukum Islam jika utang memiliki bunga yang telah ditentukan dari pokok pinjaman maka bunga tersebut termasuk ke dalam riba. Riba yang termasuk dalam perjanjian utang piutang adalah Riba Qardh. Riba Qardh adalah riba yang terjadi pada transaksi utang piutang yang tidak memenuhi kriteria untung muncul bersama resiko dan hasil usaha muncul bersama biaya. Dan dalam perjanjian utang piutang yang mengandung riba itu karena adanya pertukaran kewajiban menanggung beban hanya karena berjalannya waktu. Adapula ayat Al-Quran yang menguatkan yaitu :

Artinya : hai orang-orang yang beriman, janglah kamu memakan riba dengan berlipat ganda dan bertakwalah kamu kepada Allah Swt supaya kamu mendapatkan keberuntungan. (QS Ali Imran (3):130).

Menurut pendapat penulis maka jika seseorang yang memberikan pinjaman dan sifat pinjam meminjam didalam islam adalah tolong menolong dan untuk memberikan manfaat kepada orang lain maka dalam hal ini debitur jika tidak ada itikad baiknya untuk membayarkan hutangnya maka pihak debitur diajak bertemu untuk mengadakan perjanjian baru mengenai utangnya tersebut dan untuk mengurangi adanya riba yang akan bertambah dengan jangka waktu yang telah ditetapkan oleh para pihaknya.

2. Pertimbangan hakim dalam memutus perkara Pengadilan Negeri Jakarta Pusat No. 538/Pdt.G/2014/PN.JKT.PST 
Di dalam putusan Pengadilan ini hakim memberikan pertimbangan Menimbang bahwa gugatan penggugat telah lewat waktu atau daluwarsa, dikarenakan perjanjian telah dibuat tahun 1978 sedangkan baru diajukan gugatan tahun 11 November 2014 sudah berjalan 34 tahun sehingga telah melampaui tenggang waktu daluwarsa selama 30 tahun sebagaimana ditentukan dalam Pasal 1967 KUHPerdata. Menimbang bahwa tergugat menandatangi surat perjanjian pinjam uang tersebut dikarenakan disuruh orang tuanya. Menimbang bahwa dengan pernyataan tergugat tersebut maka tergugat mengakui adanya hutang kepada penggugat, namun dalam fakta dipersidangan tergugat tidak dapat membuktikan bahwa hutang tersebut adalah untuk orang tuanya. Menimbang bahwa seandainya benar orang tuanya yang menyuruh maka tetap yang bertanggung jawab bila orang tuanya meninggal dunia adalah anaknya (tergugat). Menimbang bahwa dikarenakan hutang tergugat kepada penggugat adalah hutang uang maka bila tergugat terbukti melakukan wanprestasi maka tergugat harus mengembalikan hutangnya kepada penggugat sesuai dengan yang diperjanjiakan. Menimbang bahwa berkaitan dengan jaminan tanah beserta gedung yang berdiri diatasnya tidak dapat begitu saja menjadi pelunasannya tetapi harus ada perbuatan hukum tersendiri yaitu dengan cara penjualan barang jaminan/lelang dan hasilnya digunakan untuk melunasi hutang tergugat dan bila terdapat sisa uang akan dikembalikan kepada tergugat. Menimbang bahwa mengenai tuntutan penggugat dalam petitum angka tujuh yaitu mohon supaya sertifikat HGB No 188/ Mangga Dua Selatan dan Sertifikat No 189/ Mangga Dua Selatan sekiranya nanti putusan aquo sudah mempunyai hukum tetap tersebut bisa dilaksanakan sita jaminan.

Menurut pendapat penulis hakim benar dalam memutuskan perkara ini karena di dalam putusan tersebut benar bahwa gugatan tersebut telah daluwarsa tetapi jika dilihat lagi ada utang yang perlu dibayarkan. Karena di dalam pasal 1320 KUHPerdata sudah adanya kesepakatan yang tercatat antara kedua belah pihak 
yang mana mengikatkan para pihak untuk melakukan perjanjian. Karena, jika seseorang telah melakukan kesepakatan untuk mengadakan perjanjian maka yang menjadi dasar dari mengikatkan diri itu ialah kehendak atau niat dari para pihaknya. Di dalam pasal 1313 KUHPerdata menyatakan bahwa suatu perbuatan dengan mana satu orang atau lebih mengikatkan dirinya terhadap satu orang atau lebih, perjanjian ini dapat berupa perjanjian pinjam meminjam, perjanjian sewa menyewa, perjanjian jual beli. Maka, dalam perjanjian tersebut yang memberikan sebuah jaminan tetapi sebuah jaminan tersebut tidak di ikatkan dalam Hak Tanggungan atau Hipotik. Jika tidak diberikan jaminan berupa Hak Tanggungan atau Hipotik dalam pembuktiannya pihak kreditur akan lemah dalam pembuktian di pengadilan apalagi debitur meminjamkan uangnya dengan perjanjian dibawah tangan berdasarkan kesepakatan para pihaknya saja dan tidak disertai dengan adanya saksi yang ikut dalam menandatangi perjanjian yang telah mereka buat.

Menurut pendapat penulis dalam perjanjian utang piutang yang memberikan jaminan harus diberikan jaminan berupa hipotik dan hak tanggungan Tetapi setelah dikeluarkannnya undang-undang hak tanggungan maka terhadap jaminan atas tanah berlaku hak tanggungan, sehingga hipotik hanya tinggal untuk kapal laut saja. Adapun undang-undang yang meninjau mengenai Hak tanggungan ini yaitu Undang-undang Nomor 4 tahun 1996 tentang Hak Tanggungan. Dalam hak jaminan atas tanah UUPA juga mengenal yang dinamakan Hak Tanggungan. Menurut UUPA, Hak Tanggungan itu dapat dibebankan diatas tanah Hak Milik (Pasal 25), Hak Guna Usaha (Pasal 33) dan Hak Guna Bangunan (Pasal 39). Menurut Undang-undang Hak Tanggungan Nomor 4 tahun 1996 didalam Pasal 4 bahwa hak Tanggungan terhadap hak atas tanah yang dapat dibebani Hak tanggungan ialah Hak Milik, Hak Guna Usaha, Hak Guna Bangunan, Hak Pakai atas tanah negara, yang menurut ketentuan harus dicatatkan dan bisa berpindah 
kepada pihak lain, yakni atas hak lahan serta bangunan dan tumbuhan, termasuk karya lainnya yang menyatu dengan lahan itu, dikuasai oleh pemilik hak atas lahan.

Hak tanggungan adalah suatu jaminan atas pembayaran utang karena itu sebelum ada hak tanggungan maka terlebih dahulu ada utang piutang. Utang piutang ini terbit antara lain dari suatu perjanjian. Apabila perjanjian utang piutang tidak diikuti dengan pembuatan akta hak tanggungan maka peralihan hak tanggungan tidak dapat di daftarkan. Kewajiban pendaftaran hak tanggungan sangat diperlukan untuk mendapatkan kepastian hukum dan untuk memenuhi unsur publisitas. Undang-undang hak tanggungan menentukan bahwa hak tanggungan wajib didaftarkan di kantor pertanahan setempat (di dalam Pasal 16 ayat 3 undangundang Hak Tanggungan). Dengan di daftarkan di kantor pertanahan maka pemegang hak tanggungan mendapatkan sertifikat Hak Tanggungan. Di dalam Pasal 13 undang-undang Hak Tanggungan menerangkan bahwa pembuatan akta pemberian hak tanggungan itu saja tidak berarti hak tanggungan sudah lahir. Lahirnya hak tanggungan tersebut adalah ketika pada tanggal buku tanah hak tanggungan yang dibuat oleh kantor pertanahan. Menurut penulis jika telah didaftarkan hak tanggungan tersebut maka dapat dialihkan hak tanggungan tersebut karena untuk melindungi kepentingan kreditur apabila debitur tidak dapat melunasi hutangnya tersebut. Apabila, debitur cedera janji maka dapat dilakukan pelaksanaan eksekusi yang diatur dalam Pasal 20 ayat 1 huruf $\mathrm{b}$ undang-undang hak tanggungan) objek yang menjadi hak tanggungan atas kekuasaan dapat dijual melalui lelang umum untuk pelunasan piutang pemegang Hak Tanggungan dengan hak mendahului dari pada kreditor-kreditor lain. Eksekusi juga bisa dilakukan dengan berbagai cara penjualan obyek tanggungan salah satunya adalah dengan cara dibawah tangan. 
Menurut pendapat penulis eksekusi Hak Tanggungan baiknya harus dilaksanakan dengan cara pelelangan umum karena dengan cara ini diharapkan agar obyek yang dijual mendapatkan harga yang diinginkan terhadap obyek Hak Tanggungan. Jika obyek Hak Tanggungan dijual dengan harga tinggi dapat melunasi hutangnya kepada kreditor maka jika memiliki sisa dapat di berikan kembali kepada debitor. Maka dengan dibuatkan akta pemberian Hak Tanggungan yang diterbitkan langsung oleh Kantor Pertanahan berupa sertifikat Hak Tanggungan. Di dalam sertifikat tersebut memuat irah-irah "DEMI KEADILAN YANG MAHA ESA” (Pasal14 Undang-Undang Hak Tanggungan Nomor 4 Tahun 1996). Dengan adanya sertifikat Hak Tanggungan maka mempunyai kekuatan eksekutorial yang sama dengan putusan pengadilan yang mempunyai kekuatan hukum tetap.

Menurut penulis dalam kasus ini terdapat kelemahan oleh karena itu jika seorang debitur memberikan sebuah jaminan berupa tanah kepada kreditor maka sebaiknya harus diberikan jaminan berupa Hak Tanggungan karena jika dikemudian hari debitur lalai dalam melunaskan utangnya maka dapat dilakukan eksekusi Hak Tanggungan oleh kreditor ke lembaga lelang umum ataupun di jual langsung dengan cara dibawah tangan, jika dijual dibawah tangan secara langsung diberitahukannya dengan adanya kesepakatan antara pemberi dan penerima hak tanggungan dan pelaksanaan penjualannya itu dilakukan setelah lewat waktu 1 bulan sejak diberitahukannya secara tertulis oleh pemberi atau pemegang hak tanggungan (Pasal 20 ayat 2 dan 3 mengenai syarat-syarat agar suatu objek Hak Tanggungan dapat dieksekusi secara langsung).

\section{B. Hasil Penelitian}

Menurut Bapak Muhammad Gunawan Yasni SE.Ak., MM, CIFA, FIIS selaku Wakil Bendahara DSN-MUI. Dalam Hukum islam orang yang memberikan pinjaman adalah transaksi kebaikan angtar umat manusia, sedangkan jika 
seseorang meminta konpensasi dari transaksi utang piutang adalah transaksi bisnis. Jadi, transaksi yang dari semula diniatkan sebagai transaksi kebaikan tidak boleh diubah menjadi transaksi bermotif bisnis. Dalam membuat perjanjian harus didasarkan atas adanya kesepakatan antara kedua belah pihak, dan dalam membuat perjanjiannya juga harus secara tertulis jelas dan terang mengenai apa yang ingin dipinjam dan obyek yang menjadi jaminan terhadap apa yang dipinjamkan juga harus jelas. Di dalam perjanjian utang Piutang tersebut tidak boleh adanya penambahan bunga karena termasuk kedalam riba. Menurut islam riba berarti menambahkan beban kepada pihak yang berhutang, riba merupakan penyakit ekonomi masyarakat yang telah dikenal lama dalam peradaban manusia. Beberapa pakar ekonomi memperkiran bahwa riba telah ada sejak manusia mengenal uang (emas dan perak). Riba juga mempunyai dampak yang besar bagi seorang muslim, bahwa seorang muslim meyakini segala sesuatu yang diharamkan oleh Allah pasti memilki dampak yang tidak baik bagi manusia, dan tidak membawa keberkahan bagi hidup manusia tesrsebut maka dari itu, Riba salah satu yang diharamkan oleh Allah dan merupakan salah satu dosa besar yang pasti berakibat buruk terhadap pribadi, masyarakat, dan ekonomi. Riba dibagi menjadi 2 bentuk yaitu riba dayn (Qard) dan riba bai'i, yang dimaksud dengan riba dayn adalah seseorang meminjam uang dikembalikan dengan berlebih dan ini masuk kedalam riba jahiliyah.riba ba'i adalah transkasi yang dilakukan ialah jual beli, tukar menukar barang dengan barang atau barang dengan uang.

Selanjutnya menurut bapak Rivai, SH Berdasarkan hukum islam orang yang memberikan pinjaman uang sifatnya adalah tolong menolong jadi harus mempunyai niatan yang baik antara para pihak. Didalam hukum islam orang yang melakukan perjanjian harus dibuat secara tertulis dan harus mempunyai 2 orang saksi, jika perjanjian itu dilakukan dibawah tangan antara individu dengan individu maka harus ada saksi yang didatangkannya seperti pejabat yang 
berwenang setempat atau kerabat dekat lainnya. Karena didalam hukum islam sudah ada aturan-aturan agama yang mengatur secara jelas dan terinci mengenai perjanjian yang akan dibuat oleh setiap manusia. Dan dalam perjanjian utang piutang tersebut jika ada bunga yang harus dibayarkan oleh debitur maka itu termasuk kedalam riba. Dalam hukum islam perjanjian bisa hapus tetapi jika seseorang mempunyai hutang maka hutangnya harus tetap dibayarkan sampai seseorang itu meninggal dunia yang dapat dipertanggungjawabkan oleh ahli warisnya.

Menurut Bapak Dr.S.Atalim, S.H.,M.H. selaku Dosen Fakultas Hukum Tarumanagara. Di lihat dari Peraturan Perundang-undangan mengenai jangka waktu hapusnya perjanjian ialah 30 tahun tetapi didalam kasus ini harus dilihat dari pertimbangan hakimnya yang mengikuti rasa kepatutan dan keadilan yang ada di dalam masyarakatnya yang semakin luas dan berkembang. Dan di lihat pula mengenai teori dari Daluwarsa jika memang telah terjadi daluwarasa maka ada 2 hak yaitu daluwarsa membebaskan dan memperoleh. Dan jika terjadi wanprestasi maka dari pihak debitur bisa menyangkal mengapa sudah lama waktunya terhadap utang tersebut baru di tagih pembayarannya dan dapat hapus begitu saja jika ada penyangkalan dari pihak debiturnya.

\section{PENUTUP}

\section{A. Kesimpulan}

Berdasarkan uraian yang telah dipaparkan diatas dan sesuai dengan permasalahan yang ada dalam Jurnal ini, maka penulis dapat menyimpulkan:

1. Bahwa dalam membuat perjanjian maka adanya hak dan kewajiban yang harus dipenuhi oleh salah satu pihak karena dalam membuat perjanjian para pihak telah sepakat apalagi dalam perjanjian utang piutang adanya hak dan kewajiban yang harus dipenuhi dan dalam perjanjian utang piutang dalam kasus ini hanya perjanjian yang dilakukan dibawah tangan secara tertulis oleh para pihak saja 
dan tidak di hadiri oleh saksi maka hanya ada kesepakatan oleh para pihak dan perjanjian tersebut harus di laksanakan oleh para pihaknya karena telah di buat perjanjian tersebut. Dalam kasus ini perjanjian utang piutang yang telah dibuat oleh para pihak pada tahun 1979-1980 seharusnya di taati pada saat itu tetapi pada kenyataanya pihak debitur lalai tidak membayarkan utangnya maka dapat dikatakan bahwa tidak terpenuhinya prestasi yang diperjanjikan oleh para pihak sehingga pihak kreditur dirugikan. Akibatnya di dalam pasal 1362 KUHPerdata dikatakan bahwa jika terjadi wanprestasi maka adanya ganti kerugian. Dan pada prinsipnya walupun dalam perjanjian ini telah daluwarsa. Daluwarsa juga dapat memperoleh sesuatu apabila dengan lewatnya waktu dan harus ada syarat-syarat tertentu (Acquisitieve Verjaring). Dalam teori ini maka harus adanya tanggung jawab yang dilakukan oleh pihak debitur karena adanya utang yang harus dibayarkan dan adapun jaminan gedung yang harusnya dijual oleh pihak debitur untuk membayarkan hutangnya tersebut.

Menurut hukum islam jika terjadi utang piutang maka utang tersebut haruslah tetap dibayarkan karena dalam hukum islam jika orang tersebut berhutang maka tidak ada istilah daluwarsa. Dalam hukum islam yang daluwarsa adalah perjanjian yang dibuat oleh para pihaknya tetapi utangnya tidaklah mengenal daluwrasa dan jika pihak debitur tersebut meninggal dunia maka yang wajib membayarkan utangnya adalah ahli warisnya. Jika ahli warisnya keberatan dengan adanya perjanjian yang terdahulu maka dapat dibuatkan adanya perjanjian yang baru agar utangnya tersebut terbayar dengan lunas kepada pihak kreditur

2. Dalam membuat perjanjian apabila telah lewat waktu maka harus segera memberitahukan kepada pihak debitur untuk segera membayarkan utangnya tersebut. Dan jika berlarut-larut maka akan merugikan pihak kreditur terhadap 
utangnya. Apabila pihak debitur memberikan sebuah jaminan benda kepada kreditur maka sebaiknya harus dijaminkan dengan hak tanggungan maka dapat dilakukan pelaksanaan eksekusi di dalam Pasal 20 ayat 1 huruf b undangundang hak tanggungan) objek yang menjadi hak tanggungan atas kekuasaan dapat dijual melalui lelang umum untuk pelunasan piutang pemegang Hak Tanggungan dengan hak mendahului dari pada kreditor-kreditor lain. Eksekusi juga bisa dilakukan dengan cara penjualan obyek tanggungan dilaksanakan dibawah tangan. Jika tidak dijaminkan dengan hak tanggungan maka pihak kreditur akan dirugikan karena jika telah lewat jangka waktu perjanjian yang telah disepakati tidak dapat di eksekusi oleh pihak kreditur untuk melunasi utangnya. Adapun hambatan jika hak Tanggungan akan dilelang yaitu objek jaminan hak Tanggungan harus segera dikosongkan,adanya gugatan dari pihak ketiga. Jika dengan cara lelang tidak dilakukan karena obyek jaminan tidak dijaminkan dengan hak tanggungan maka para pihak dapat di pertemukan untuk melakukan musyawarah dan mufakat dengan para pihaknya melalui negosiasi. Negosiasi adalah proses saat dua pihak mencapai perjanjian yang dapat memenuhi kepuasan termasuk di dalamnya tindakan yang dilakukan ketika berkomunikasi, kerjasama atau memengaruhi orang lain dengan tujuan tertentu. Jikalau dengan cara negosiasi tersebut tidak menemukan titik terang maka dapat mengajukan gugatan baru. Gugatan baru tersebut yaitu gugatan pidana. Karena jika utang piutang tidak dibayarkan maka dapat kasus pidana apabila di dalamnya ada unsur penggelapan dan atau penipuan sebagaimana terdapat pada Pasal 372 dan Pasal 378 KUHP dengan sanksi berupa pidana penjara paling lama 4 (empat) tahun atau pidana denda paling banyak sembilan ratus rupiah

\section{B. Saran}

Berdasarkan pemaparan diatas penulis menyarankan : 
1. Dalam membuat perjanjian seharusnya jika perjanjian dibawah tangan dengan tertulis harus di datangkan saksi-saksi dan jika perjanjian tersebut memiliki jaminan sebaiknya jaminan tersebut diikatkan dengan hak tanggungan atau hipotik dan jika perjanjian tersebut tahun 1978-1980 harusnya dilakukan penagihan pada waktu yang dekat dengan tahun tersebut sehingga pihak kreditur mendapatkan haknya dari pihak debitur dan tidak mengalami daluwarsa. Jika telah mengalami daluwarsa maka harus dibuatkan perjanjian baru antara para pihak untuk dipertemukan kembali mengenai utang yang harus dibayarkan.

2. Bagi masyarakat yang ingin melakukan perjanjian harusnya lebih berhati-hati apabila memiliki perjanjian yang memilki jangka waktu yang telah disepakati maka harus segara di bayarkan agar mendapatkan haknya. Dan memberikan pemahaman kepada masyarakat tentang pentingnya akta otentik guna menjamin kepastian hukum.

\section{DAFTAR PUSTAKA}

\section{A. Buku}

Soerjopratiknjo, Hartono. Hutang pihutang perjanjian-perjanjian pembayaran dan jaminan hypotik, cetakan ke-1. Yogyakarta:Seksi Notariat Fakultas HukumUniversitas Gadjah Mada,1984.

Subekti. Hukum perjanjian, Cetakan ke-16. Jakarta:PT. Intermasa, 1996. . Hukum Perjanjian, Cetakan ke-20. Jakarta: PT. Intermasa, 2004. . Jaminan-jaminan untuk pemberian kredit menurut hukum Indonesia.

Bandung:Alumni, 1978.

\section{B. Wawancara}


Peneliti, Wawancara, dengan Ustad. H. Solihin, S.Ag (Jakarta, Guru Agama dan Fiqih SMA Al-Chasanah, 17 Oktober 2018).

Penulis, Wawancara dengan Bapak Muhammad Gunawan Yasni SE.Ak., MM, CIFA, FIIS. Selaku Wakil Bendahara DSN-MUI, 23 November

Penulis, Wawancara dengan Bapak Dr.S.Atalim, S.H,M.H. Selaku Dosen

Universitas Tarumanagara, di Perpustakan Universitas Tarumanagara Jakarta Barat, 27 November.

\section{Internet}

Anonim, "Surat Al-Maidah ayat 2",

https://www.bacaanmadani.com/2017/12/pengertian-hukum-dalil-danketentuan.html, 17 Oktober 2018. 